\title{
Health prevention training for foster child care facility personnel
}

\author{
María E. Serra, M.D. ${ }^{a}$ and Rose Mari Soria, B.S. ${ }^{a}$
}

\begin{abstract}
In Argentina there are more than 9000 children without parental care due to prior abuse or neglect, assisted in foster child care facilities. The quality of care provided there impacts on the well-being of children and on multiple aspects of their adult life. Prevention in health in this setting has its own characteristics. Lack of policies that guarantee good practices, not only concerns to the exercise of the right to health established by the Convention on the Rights of the Child, but also conditions the exercise of other rights.

Care requires knowledge, skills and attitudes appropriate to the needs of children. The experience, difficulties and perspectives of the first health training program for foster child care facilities personnel in Argentina are presented. Key words: institutional care, health promotion, training, child care quality.
\end{abstract}

http:/ / dx.doi.org/10.5546/ aap.2019.eng.e598

To cite: Serra ME, Soria RM. Health prevention training for foster child care facility personnel. Arch Argent Pediatr 2019;117(6):e598-e605.

a. Health Prevention Program for Child Care Centers, Foundation for MaternalInfant Health (FUNDASAMIN), Autonomous City of Buenos Aires.

E-mail address:

María E. Serra, M.D.: meserra@fundasamin. org.ar

\section{Funding:}

The training program presented here was funded through a grant accredited by the Call for Projects to Strengthen the Civil Society, by the Ministry of Human Development and Environment of the Autonomous City of Buenos Aires..

\section{Conflict of interest:} None.

Received: 1-10-2019 Accepted: 5-2-2019
Adversity during childhood impacts on infant development and different biological systems. ${ }^{3,4}$ It is related to anxiety disorders, drug addiction, depression, posttraumatic stress disorder, and cardiovascular, gastrointestinal, metabolic, neurological, musculoskeletal and respiratory disease during adulthood. ${ }^{5}$ It affects child development through synergistic mechanisms. These include changes in energy metabolism, which result in growth, cerebral structure, and neurocognitive function disorders; immune system activation, which leads to acute or chronic inflammation; and the deregulation of the hypothalamo-pituitary-adrenal axis, which affects neuroendocrine response to stress. ${ }^{6}$

Child's health status determines growth and development, as well as the full expression of his potentials. An adequate health status is a fundamental right, necessary to ensure the full exercise of other rights. ${ }^{7}$ To this end, it is essential to provide high quality care because it has demonstrated to be a protective factor for an adequate child development, and it may even ameliorate consequences of previous adverse experiences. ${ }^{8,9}$

In this regard, the professionalization of caregivers is critical. Specific training would have an impact not only on their individual actions but also on other critical elements that lead to quality. The importance of caregivers' role is related to the children's current health status but extends over time, because they may be the only adult model for those children and have a chance to determine healthy habits and how to interact with other people for the rest of their lives.

Care, provided by foster care facilities caregivers, requires adequate 
knowledge, skills, and attitudes in relation to different childhood needs. Therefore, international and local guidelines and standards $\mathrm{s}^{1,10,11}$ have established that the personnel in charge require initial and continuous training. However, caregivers are not professionals because, to date, both in Argentina and in many Latin American countries, ${ }^{12}$ there is no job profile defined for this role or standard training requirements that would allow to ensure a minimum level of health care quality in this setting.

Based on the above, and on the needs detected by a previous joint study by our team and the General Office for Childhood and Adolescence (Dirección General de Niñez y Adolescencia, DGNyA) of the Autonomous City of Buenos Aires, a health prevention training program was proposed for caregivers working at foster care facilities for children and adolescents, to be conducted at Fundación para la Salud Materno Infantil (FUNDASAMIN). It was aimed at caregivers and its objective was to improve the quality of care provided at these alternative care institutions. The secondary objective of this educational experience was to detect and solve issues with the implementation of preventive measures.

In this article, we describe the experience, difficulties, and perspectives of the first health prevention training program for caregivers working in foster care facilities for children and adolescents in Argentina.

\section{TRAINING PROGRAM DEVELOPMENT}

The training consisted in a series of eight 3-hour weekly sessions (class and workshop format), which were funded through the Call for Projects to Strengthen the Civil Society (Ministry of Human Development and Housing of the Autonomous City of Buenos Aires).

The activity was supplemented with modules offered by the DGNyA, which focused on psychological, legal, and institutional aspects.

The program was made up of 3 stages.

\section{First stage: Design}

The following cross-cutting training themes were established during this stage:

- Difference between family homes and foster care facilities.

- Risk prevention.

- Caregivers' responsibilities.

- Caregivers' role as promoters of healthy habits.
- Quality of care and child and caregiver wellbeing.

The health contents necessary for the performance of such role were selected (Table 1) and adapted to the profile determined by the Training Area of the DGNyA. The most common and relevant medical conditions and key care procedures in this social context were taken into consideration. Specialized health care as offered in health care institutions was explicitly excluded. Teaching resources (classes, workshops, and reading material) and a comprehensive exam were planned.

\section{Second stage: Caregiver training}

The Foster Child Care Facilities Office of the DGNyA was in charge of promoting the activity, and the invitation was extended to the 5 foster care facilities managed by the Government of the Autonomous City of Buenos Aires (GCBA). Content development was supplemented with the implementation of a practical activity. Before training initiation, a meeting was held with the coordinators and/or directors of the 5 facilities managed by the GCBA and two management officers of the area. Five of them agreed that the most alarming issue was infection spreading. In terms of improvement expectations, they mentioned a more effective response to medical emergencies, cot injury prevention (sudden death, asphyxia, and choking), different hygiene-related procedures, and early detection of developmental and behavior disorders. In this meeting, documents containing guidelines developed in advance by our team on different aspects of health-related prevention were delivered to supplement training.

Three training cohorts took place between April 2017 and June 2018. The program offered

\section{TABLE 1. Training themes}

Thematic units

- Healthy growth and development

- General child care

- Adolescence

- Safe and healthy nutrition

- Common childhood diseases

- Infection prevention

- Unintentional injury prevention

- Safe sleep

- Mistreatment and abuse

- Emerging events

- Medication management and administration

- Caregivers' health 
90 vacancies. A total of 47 caregivers from the 5 foster care facilities managed by the GCBA were enrolled (Table 2). Face-to-face sessions were conducted at the FUNDASAMIN building to avoid the unnecessary intrusion of people at foster care facilities and the overlapping of training and care duties.

An initial, anonymous diagnostic survey was administered to participants to assess their knowledge on basic health issues and to know their training expectations. The voluntary survey was completed by 44 participants. Of them, 13 answered correctly the questions about safe sleep, 40 about emergency procedures, and 36 about safe play. Table 3 shows the themes described as most alarming.

Themes were approached from the perspective of caregivers' responsibilities in relation to health prevention: being able to provide quality, individualized care with an adequate warning level for the characteristic health situation of a closed community setting.

The DGNyA representative responsible for training participated in the sessions, which enabled her to answer any specific questions and provide guidance for effective implementation of measures based on examples of her own experience and telling health related episodes and events which occurred at different times and foster care facilities.

Concerns mentioned during the informal exchange on the factors that facilitated or obstructed the exercise of the right to health during face to face sessions were recorded so as to systematize and report them, and to propose specific improvements (Table 4).

TABLE 2. Participants who enrolled and received training by foster care facility where they worked

\begin{tabular}{lccc}
\hline $\begin{array}{l}\text { Foster } \\
\text { care facility }\end{array}$ & \multicolumn{2}{c}{ Participants } & $\begin{array}{c}\text { Total } \\
\text { personnel }\end{array}$ \\
\hline & Enrolled & Trained & \\
\hline A & 8 & 3 & 42 \\
B & 13 & 8 & 28 \\
C & 7 & 7 & 40 \\
D & 13 & 12 & 33 \\
E & 6 & 7 & 22 \\
Total & 47 & 37 & 165 \\
\hline
\end{tabular}

* Three caregivers who did not work at the government-managed foster care facilities also received training (they had been invited to participate due to the open vacancies).
When these training cycles ended, 37 caregivers met the attendance requirements (6 out of 8 sessions). The final exam consisted in a set of multiple choice questions on routine situations faced by caregivers as part of their duties. The 37 caregivers who had completed the training cycle passed the exam (more than $70 \%$ of correct answers) (Table 2).

\section{Third stage: Program assessment} with feedback from foster care facilities

During the last session, the 37 participants completed an individual, self-administered,

TABLE 3. Health-related concerns among caregivers

\begin{tabular}{lc}
\hline Most alarming issues & $\begin{array}{c}\text { No. of participants who } \\
\text { mentioned it }(\mathbf{n}=\mathbf{4 4})\end{array}$ \\
\hline Infections & 34 \\
Mental health & 8 \\
Nutrition & 5 \\
Sexuality & 4 \\
Addictions & 4 \\
Hygiene & 4 \\
Bronchospasm & 4 \\
HIV infection & 4 \\
Personnel training & 3 \\
Medication & 3 \\
Safety (unintentional injuries) & 1 \\
Other (CPR, seizures, etc.) & 11 \\
\hline
\end{tabular}

HIV: human immunodeficiency virus;

CPR: cardiopulmonary resuscitation.

TABLE 4. Concerns mentioned during sessions

- Lack of standardization for emergency procedures.

- Lack of knowledge on medication storage, administration, and care.

- Dichotomy between the actions performed at a foster care facility and at a hospital: lack of implementation of simple preventive measures, as opposed to the use of equipment and technology typical of a health care facility (e.g., a pulse oximeter).

- Poor expectations in relation to the implementation of what was learned due to a lack of interest in training and in the possibility of improvement among the personnel.

- Difficulty access to emergency medical care.

- Follow-up health care taking place at different facilities. No formal coordination to simplify access to diagnostic tests or treatments.

- Informal employment managed through temporary contracts. Lack of defined minimal conditions to be met and not always having the pre-employment health checkups necessary for the work setting.

- The complex routine operation of a foster care facility, which sometimes resulted in insufficient human resources available, even when, from a regulatory perspective, the specified number of personnel was met.

- Periodic infrastructure and utility problems. 
anonymous, written reflection about the expectations and possibilities of implementing the program contents (see Annex). When asked about which 3 measures they considered could be immediately implemented at the setting where they worked, 3 said none; 21 said 1; and the other 13, more than 1 . In relation to whether they planned to propose prevention-related improvements to the institution technical team, 7 said they would not propose any improvement; 17 , only 1 ; and 13 , more than 1 .

The measures considered more feasible for immediate adoption were those related to hand hygiene (14), medication management and administration (8), and organizational aspects (5).

The main themes that they would propose to the technical team were hand hygiene (9), timely medical care (5), medication administration (5), training for the entire personnel, including the technical team (4), safe environment (4), and organizational aspects (4).

In relation to feasibility, caregivers perceived difficulties for the implementation of, mainly, a functional and safe environment (16), hand hygiene procedures (9), personnel training (9), and adequate, timely, and accessible medical care (8).

A final meeting with the directors and the Foster Child Care Facilities Office was held to exchange experiences regarding barriers at the time of developing and implementing the training.

\section{DISCUSSION}

This first experience of health prevention training for caregivers was well accepted by participants and showed good results in terms of knowledge acquisition. Although some training experiences for personnel working at foster care facilities have been published, they took place in other regions. ${ }^{13-17}$ In Latin America, two educational interventions were recorded for foster care facility caregivers, exclusively focused on infant development and with small sample size, as in this case. 18,19

The number of enrolled participants was lower than the open vacancies. This, in addition to the loss of participants who failed to complete the training, displayed the difficulties posed by the lack of time to receive training in the work setting. Also, one third of participants mentioned this was one of the most difficult health prevention actions to implement. In spite of the commitment of the Foster Child Care Facilities Office and the expectations and interest expressed by coordinators and directors, each foster care facility routine dynamics and human resource availability may be an obstacle that cannot always be overcome for the implementation of training. The program is currently offered in a distance, asynchronous learning modality as an option to overcome such difficulty.

The level of baseline knowledge was higher than that observed in previous trainings on specific topics performed by our team and than the expected level given the fact that there are no training requirements to perform these duties. This may be explained because it was a voluntary training and there may be a bias in relation to interest and eventual prior knowledge on this topic. Still, it is concerning that only one third of participants answered correctly on how to prevent sudden infant death, an epidemiologically relevant topic for infants in this setting ${ }^{20}$ and this was taken as a priority for directors and coordinators.

The spreading of infections was the most important concern for both coordinators and caregivers. During 2015, our team, with the financial support of the DGNyA, developed a guideline on infection prevention, ${ }^{21}$ held training sessions and, at the same time, provided institutions with the necessary supplies for the implementation of preventive measures. However, as arised in the sessions, these measures are implemented in heterogeneous and inconsistent manner.

Although medication management and administration is a critical aspect of routine foster care duties, with potentially severe consequences, only 3 caregivers mentioned it as a concerning topic, and none of the coordinators or directors.

Even though most participants answered correctly on emergency management, this was also a concern for directors. The exchange showed that emergency procedures are not standardized. Also, safety was not one of the most concerning themes among caregivers, in spite of being the leading cause of death in children older than 1 year, the operation and infrastructure conditions that may affect safety, and the well-known unfortunate events that have taken place in CABA and other regions. ${ }^{22,23}$

When exploring the feasibility of implementing preventive measures, 3 participants did not consider the possibility of proposing or making immediate changes. This shows certain skepticism about the possibility of improvement, 
which was openly discussed during the sessions. This seems to have different reasons, from lack of supplies or an inadequate infrastructure to the idea that, within working teams, members are not always willing enough to make changes in the operation and organization of duties.

In addition, there is a contradiction between the answers about which measures they consider could be implemented immediately and those that they do not see feasible, and this may be because of differences in institution's resources and operation and different perceptions about the reality of caregivers' working environments.

The most commonly proposed measures were related to organizational aspects. The informal exchange allowed to perceive lack of role definition by the management of each foster care facility, which leads to making personal decisions when faced with problematic situations that would require established institutional solutions. Both directors and technical teams are responsible for different aspects of children's well-being and manage urgent and diverse situations on a daily basis, which may take time away from a longterm plan for the subject matter of this article. Such difficulty is beyond what the technical team or coordinators can handle and requires central support, through documents and protocols, as well as the possibility of delegating this task to specifically trained personnel. ${ }^{24}$

Access to timely medical care is one of the most difficult actions to implement. This point, which corresponds to a management level beyond the individual institutional direction, is, in our opinion, a priority. Formal coordination with the health system would allow to offer better medical care to each child that requires it, safeguard the health of the rest, and reduce costs. ${ }^{25}$

Precarious job conditions, in addition to the physical and emotional efforts made by caregivers, favor the frequent staff turnover, with the resulting negative consequences: disrupted attachment, poorly trained and motivated personnel, ineffective team work dynamics, etc. ${ }^{26,27}$

This project aims to provide educational contributions, understanding the power to transform reality as the core of education. Although impact indicators may be proposed, this entails methodological difficulties because of the type of action and multiple factors affecting final outcomes (children with a better health status),.$^{28}$

In any case, proposed health prevention measures have demonstrated to be sufficiently effective so, if the fact that knowledge and implementation are higher than before the intervention could be corroborated, it should be inferred that some impact occurs, even if it is not possible to establish its magnitude. ${ }^{29}$

In addition, this first experience included a small sample of caregivers. It is necessary to maintain the training program over time to reach everyone playing this role in their jobs. However, it is promising that all regular participants passed the exam and that, among the different proposed measures, topics that they had not considered relevant before stood out (e.g., medication).

The obstacles observed for implementation of improved care are the same as those described by other institutions, in Latin America and other countries. ${ }^{11,17,30-32}$ This is a multidimensional and complex issue. However, it is worth noting the willingness authorities and their technical teams to actively collaborate with the proposed intervention as well as to provide training options about other key aspects that would encourage caregivers' professionalization.

This article provides value as a means to promote the inclusion of childhood at foster care in the public agenda. To our knowledge, this is the description of the first educational experience of this kind in Argentina, conducted as a joint effort among the stakeholders of civil society and the government to improve the quality of care provided to vulnerable children based on international guidelines. The determining factors of the problem to a full exercise of the right to health in this setting undoubtedly require other actions, such as defining the profile of caregivers, including attributes, requirements, and the scope of their role, establishing guidelines to standardize practices, developing a performance assessment, ensuring the continuous availability of human resources and supplies to implement preventive measures, and adequately coordinating with the health system. Basic training on children carerelated themes in this situation has direct and short-term implications on health, and it becomes an essential step to warrant a minimum standard of care quality.

\section{CONCLUSION AND PERSPECTIVES}

Our expectations are that trained caregivers will generate changes in their work environments, not only through the implementation of preventive measures but also as creators of awareness and communicators of good health prevention practices for the rest of caregivers. 
The future challenge is to professionalize all foster child care facilities caregivers, to maintain this training course over time, and to make it a preemployment requirement.

\section{Acknowledgments}

We would like to thank Andy Cisneros, B.S., Gladys Sotto, B.S., and Víctor Fernández, B.S., members of the DGNyA, for their active participation in caregiver training and for making this first experience possible.

\section{REFERENCES}

1. UNICEF-Ministerio de Desarrollo Social de la Nación. Situación de niños, niñas y adolescentes sin cuidados parentales en la República Argentina: relevamiento nacional- actualización 2014. Buenos Aires; 2015. [Accessed on: January 9 $\left.9^{\text {th }}, 2019\right]$. Available at: https:// www.unicef.org/argentina/sites / unicef.org.argentina / files / 2018-04 / PROTECCION_Relevamiento_ SinCuidadosParentales2015_b.pdf.

2. Szilagyi MA, Rosen DS, Rubin D, Zlotnik S, et al. Health Care Issues for Children and Adolescents in Foster Care and Kinship Care. Pediatrics. 2015; 136(4):e1142-66.

3. Berens AE, Jensen SKG, Nelson CA 3rd. Biological embedding of childhood adversity: from physiological mechanisms to clinical implications. BMC Med. 2017; 15(1):135.

4. Jensen SKG, Berens AE, Nelson CA 3rd. Effects of poverty on interacting biological systems underlying child development. Lancet Child Adolesc Health. 2017; 1(3):225-39.

5. Gonzalez A. The impact of childhood maltreatment on biological systems: Implications for clinical interventions. Paediatr Child Health. 2013; 18(8):415-8.

6. Turner RJ, Thomas CS, Brown TH. Childhood adversity and adult health: Evaluating intervening mechanisms. Soc Sci Med. 2016; 156:114-24.

7. UNICEF. Convención sobre los Derechos del Niño. Panamá: UNICEF; 2016. [Accessed on: January $3^{\text {rd }}$, 2019]. Available at: https: / / www.unicef.org/panama/spanish/CDNPanama_Version_Bolsillo_Final.pdf.

8. Britto PR, Lye SJ, Proulx K, Yousafzai AK, et al. Nurturing care: promoting early childhood development. Lancet. 2017; 389(10064):91-102.

9. Black MM, Walker SP, Fernald LCH, Andersen CT, et al. Early childhood development coming of age: science through the life course. Lancet. 2017; 389(10064):77-90.

10. Organización de las Naciones Unidas. Resolución 64/142. Directrices sobre las modalidades alternativas de cuidado de los niños. 24 defeb.de 2010. [Accessed on: January $7^{\text {th }}, 2019$ ]. Available at: http: / / www.acnur.org/fileadmin/scripts / doc. php?file=fileadmin/Documentos/BDL/2010/8064.

11. Argentina. Secretaría Nacional de Niñez, Adolescencia y Familia. Lineamientos nacionales en materia de niños, niñas y adolescentes carentes de cuidados parentales. In:Memoria y balance del Consejo Federal de Niñez, Adolescencia y Familia 2007-2013. Buenos Aires: Ministerio de Desarrollo Social de la Nación; 2014:28-34. [Accessedon: December $\left.20^{\text {th }}, 2018\right]$. Available at: http: / / www.desarrollosocial.gob. ar/biblioteca / memoria-y-balance-del-cofenaf-2007-2013/.

12. PalummoJ.La situación deniños, niñas y adolescentes enlas instituciones de protección y cuidado de América Latina y elCaribe. Panamá:UNICEF; 2013. [Accessed on:December $\left.20^{\text {th }}, 2018\right]$. Available at: http:/ / redegresadoslatam.org/
wp-content/uploads/2017/11/UNICEF_Estudio_sobre_ NNA_en_instituciones.pdf.

13. Wright C, Lamsal D, Ksetree M, Sharma A, et al. From maid to mother: transforming facilities, staff training and caregiver dignity in an institutional facility for young children in Nepal. Infant Ment Health J. 2014; 35(2):132-43.

14. Berument SK. Environmental enrichment and caregiver training to support the development of birth to 6-yearolds in Turkish orphanages. Infant Ment Health J. 2013; 34(3):189-201.

15. Hemenau K, Kaltenbch E, Mkinga G, Hecker T. Improving care quality and preventing maltreatment in institutional care - a feasibility study with caregivers. Front Psychol. 2015; 6:937.

16. Sparling J, Dragomir C, Ramey SL, Florescu L. Educational intervention improves developmental progress of young children in a Romanian orphanage. Infant Ment Health J. 2005; 26(2):127-42.

17. St. Petersburg-USA Orphanage Research Team. The effects of early social-emotional and relationship experience on the development of young orphanage children. Monogr Soc Res Child Dev. 2008; 73(3):vii-295.

18. Lecannelier F, Silva JR, Hoffman M, Melo R, et al. Effects of an intervention to promote socioemotional development in terms of attachment security: a study in early institutionalization in Chile. Infant Ment Health J. 2014; 35(2):151-9.

19. McCall RB, Groark CJ, Fish Ly, Harkins D, et al. A socioemotional intervention in a Latin American orphanage. Infant Ment Health J. 2010; 31(5):521-42.

20. JenikA, Grad E, Orazi V,SapoznicoffL, etal. Consideraciones sobre el sueño seguro del lactante. Grupo de Trabajo en Muerte Súbita e Inesperada del Lactante de la Sociedad Argentina de Pediatría. [Accessed on: December 20 $0^{\text {th }}, 2018$ ]. Availableat:https:/ / www.sap.org.ar/uploads/consensos / consideraciones-sobre-el-sue-ntildeo-seguro-del-lactantegrupo-de-trabajo-en-muerte-s-uacutebita-e-inesperada-dellactante-de-la-sociedad-argentina-de-pediatr-iacutea.pdf.

21. Serra ME, Soria R. Prevención de Infecciones para Centros de Cuidado Infantil. Guía para el personal. Buenos Aíres: FUNDASAMIN-Ministerio de Desarrollo Social; 2015. [Accessedon: December 20 $0^{\text {th }}, 2018$ ]. Available at: https://drive.google.com/file/d/0B6Q tNaD963RQVFScTFac2Y3Y0k/view.

22. Dos chicos de la calle muertos al incendiarse un hogar de tránsito. La Nación. 3 de julio de 2002. [Accessedon: December $\left.17^{\text {th }}, 2018\right]$. Available at: https: / / www.lanacion. com.ar / sociedad / dos-chicos-de-la-calle-muertos-alincendiarse-un-hogar-de-transito-nid410629.

23. Un incendio mató a 19 chicas de un hogar para menores en Guatemala. La Nación. 9 de marzo de 2017. [Accessedon: December $\left.13^{\text {th }}, 2018\right]$. Available at: http:/ / www.lanacion. com.ar/1991325-un-incendio-mato-a-19-chicas-de-unhogar-para-menores-en-guatemala.

24. RELAF, UNICEF. Guía de estándares para el personal de las entidades públicas y privadas que se ocupan de la protección de derechos de niñas, niños y adolescentes. Aplicación de las directrices de las Naciones Unidas sobre las modalidades alternativas de cuidado de los niños. Buenos Aires: RELAF-UNICEF; 2010. [Accessed on: December $\left.12^{\text {th }}, 2018\right]$. Available at: https://www. unicef.org/protection/Guia_Estandares_Operadores_ Directrices_(2).pdf.

25. Woolverton M. Meeting the health care needs of children in the foster care system. Strategies for implementation. Washington, DC: Georgetown University Child Development Center; 2002. [Accessed on: December 20 ${ }^{\text {th }}$, 
2018]. Available at: https://gucchd.georgetown.edu/ products/FCStrategies.pdf.

26. Bakermans-Kranenburg MJ, Steele $\mathrm{H}$, Zeanah $\mathrm{CH}$, Muhamedrahimov RJ, et al. Attachment and emotional development in institutional care: Characteristics and catch-up. Monogr Soc Res Child Dev. 2011; 76(4):62-91.

27. Vaschenko M, Easterbrooks MA, Miller LC. Becoming their mother: knowledge, attitudes and practices of orphanage personnel in Ukraine. Infant Ment Health J. 2010;31(5):57090.

28. Hermenau K, Goessmann K, Rygaard NP, Landolt MA, etal. Fostering Child Development by Improving Care Quality: A Systematic Review of the Effectiveness of Structural Interventions and Caregiver Trainings in Institutional Care. Trauma Violence Abuse. 2017; 18(5):544-61.
29. Nebot M. Health promotion evaluation and the principle of prevention. J Epidemiol Community Health. 2006; 60(1):5-6.

30. Cortés F, Concha M. Resumen ejecutivo: diagnóstico del sistema de cuidados alternativos del estado de Chile. Centro de medición MIDE UC; 2013. [Accessed on: December $\left.7^{\text {th }}, 2018\right]$. Available at: http://mideuc. cl/wp-content/uploads/2013/11/Resumen-EjecutivoDiagn\%C3\%B3stico-Sistema-de-Cuidados-Alternativos. pdf.

31. Groark CJ, McCall R, Fish L, The whole child international evaluation team. Characteristics of environments, caregivers, and children in three Central American orphanages. Infant Ment Health J. 2011; 32(2):232-50.

32. McCall RB. The consequences of early institutionalization: can institutions be improved? - should they? Child AdolescMent Health. 2013;18(4). [Accessed on: December $\left.8^{\text {th }}, 2018\right]$. Available at: https: / / www.ncbi.nlm.nih.gov/ pmc/articles/PMC3833822/. 
ANNEX

\section{Survey}

Please answer this survey as honestly as possible based on what you believe is feasible.

1. What is your role in the foster child care facility where you work?

- Coordinator.

- Caregiver

- Member of the technical team

- Other:

2. Is there any measure or action that may contribute to children/adolescents' health that you think could be implemented in the next month at the facility where you work?

- No

- Yes

- Which ones?:

3. Is there any measure or action that may contribute to children/adolescents' health that you would propose to the technical team of the foster care facility where you work?

- No

- Yes

- Which ones?:

4. Please mention which measures or actions you would like to implement where you work but you think would not be feasible. Please explain the barriers for implementation you have detected. 